\title{
Genetical Studies on the Lipopolysaccharide Structure of Escherichia coli K12
}

\author{
By G. SCHMIDT \\ Max-Planck-Institut für Immunobiologie, D-78 Freiburg i.Br, Germany.
}

(Received I2 January 1973; revised 9 March 1973)

SUMMARY

Escherichia coli $\mathrm{K} 2 \mathrm{2}$ strain 2578 was crossed with an $E$. coli $\mathrm{O} 8$ donor. Most of the recombinants selected for the donor his allele were agglutinable by anti-O8 serum. This indicated that the recombinants can synthesize O8-specific units and attach them to the KI 2 lipopolysaccharide (LPS) core in consequence of the transfer of the his-linked donor $r f b$ cluster determining O8-chain synthesis. In serological tests and phage sensitivity tests most O8-reactive recombinants behaved like typical smooth E. coli O8 strains. This implies that E. coli KI 2 strain 2578 synthesizes a complete core structure, which is a prerequisite for the formation of smooth recombinants.

Some O8-reactive recombinants displayed a partly rough phenotype. In addition, the typical smooth recombinants segregated partly rough forms. Thus the smooth recombinants appear to be partial diploids for some donor gene(s) involved in LPS synthesis.

Serological tests and phage typing showed that the Escherichia coli K12 core is different from other known core types of Salmonella (Ra) and E. coli (RI-R3).

The genes $(r f a)$ for the KI 2 core type were mapped by conjugation at approximately 72 min on the Escherichia coli linkage map.

\section{INTRODUCTION}

The O-antigenic lipopolysaccharides (LPS) of Enterobacteriaceae consist of O-specific polysaccharide chains, composed of repeating oligosaccharide units, linked to a core oligosaccharide which in turn is bound via 2-keto-3-deoxyoctonate (KDO) to a lipid (Lüderitz, Jann \& Wheat, 1968; Lüderitz, Westphal, Staub \& Nikaido, 1971). The structure of the Salmonella LPS is presented in Fig. I. The biosynthesis of LPS is genetically determined by various $r f$ genes. Genes $r f a$ and $r f b$ are responsible for synthesis of the core oligosaccharide and the O-specific polysaccharide chains, respectively (Stocker \& Mäkelä 197I). Mutation at any of the various $r f a$ loci, most of which are clustered in the $c y s E-p y r E$ region leads to rough $(\mathrm{R})$ mutants with an incomplete core which lacks the normal site for $\mathrm{O}$-specific chain attachment. Mutation of any of the $r f b$ genes, all of which form a cluster closely linked to the histidine (his) operon blocks the synthesis of $\mathrm{O}$-specific chains and results in $\mathrm{R}$ mutants having a complete core structure. Most of today's knowledge on the genetics of LPS synthesis results from studies with Salmonella. But there are sound indications that equivalent loci exist in Escherichia coli (Ørskov \& Ørskov, I962; Schmidt, Jann \& Jann 1970).

Escherichia coli $\mathrm{K} \mathrm{I} 2$ is a phenotypically rough strain which is widely used for biochemical and genetic studies. This strain has no detectable O-antigen specificity (Ørskov \& Ørskov, I962) and its smooth parent strain is unknown. The polysaccharide portion of the lipopolysaccharide (LPS) extracted from E. coli K 12 contains glucose, galactose, heptose, 


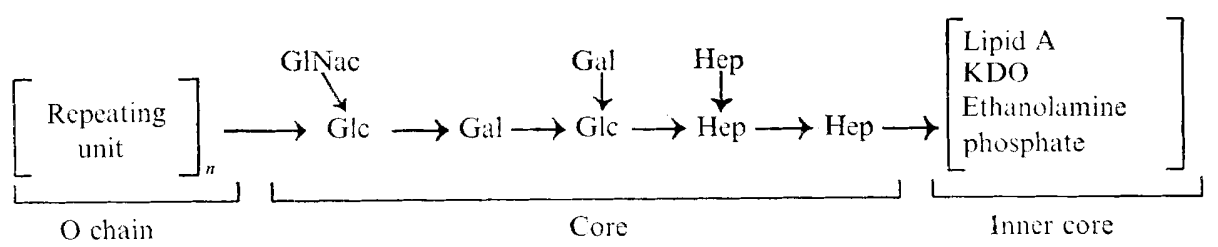

Fig. I. LPS structure of Salmonella (Lüderitz et al. I97I ; V. Lehmann, unpublished). Glc, glucose; Gal, galactose; GINaC, N-acetyl-glucosamine; Hep, heptose; KDO, 2-keto-3-deoxyoctonic acid.

KDO and small amounts of rhamnose (Nikaido, Nikaido \& Rapin, I965; Rapin \& Mayer, I 966; Sugimoto \& Okazaki, I967), but the structural arrangement of these components is still unknown.

Crosses described by Ørskov \& Ørskov ( 1962) suggested that Escherichia coli $\mathrm{KI} 2$ has defective $r f b$ genes. They crossed an E. coli KI $2 \mathrm{~F}^{+}$donor $\left(H_{i s^{+}}\right)$with a smooth $E$. coli of serotype oroo $\left(\mathrm{F}^{-}\right.$, his $)$. Recombinants selected for $\mathrm{His}^{+}$behaved like rough forms. This suggests that defective $r f b$ genes of $E$. coli KI 2 had replaced the intact recipient $r f b$ genes determining the synthesis of oroo specific polysaccharide chains.

In crosses recently described by Jones, Koeltzow \& Stocker (1972) introduction of the his-rfb region from an Escherichia coli $\mathrm{O} 8$ donor into $E$. coli $\mathrm{KI} 2$ led to hybrids with serological O8 specificity, but unlike typical smooth E. coli strains they retained sensitivity to various rough-specific phages. Several explanations for the $\mathrm{R}$-specific phage sensitivity of the hybrids were suggested by the authors including the possibility of a leaky $r f a$ mutation in the recipient.

Thus it remained uncertain whether $E$. coli KI2 also has a $r f a$ defect in addition to the $r f b$ lesions. This paper describes results which show that the $r f a$ genes necessary for the complete LPS core synthesis are intact in the Escherichia coli KI 2 strain investigated.

On the basis of serological tests and phage typing the Escherichia coli K 2 LPS core does not belong to one of the already established LPS core types of Salmonella (Ra; Lüderitz et al. I97I) and E. coli (E. coli RI-R3; Schmidt, Fromme \& Mayer, 1970), thus it represents a newly identified core type. Moreover the genes for the $\mathrm{KI} 2$ core synthesis were transferred to E. coli $\mathrm{RI}$-type mutants. The locus was mapped at a site which is apparently equivalent to that of the Salmonella $r f a$ gene cluster (Kuo \& Stocker, 1972: Sanderson \& Saeed, 1972).

\section{METHODS}

Bacterial strains. All strains used for genetic experiments are derived from Escherichia coli $\mathrm{KI} 2$ or from $E$. coli $\mathrm{O} 8: \mathrm{K}_{2} 7: \mathrm{H}^{-}\left(\mathrm{E}_{5} 6 \mathrm{~b}\right)$. The strains and their genetic markers are listed in Table I. The E. coli $\mathrm{KI} 2$ donor HfrC was provided by Drs I. and F. Orskov and the E. coli KI2 donor KL25 was obtained from Dr B. Low (Low, 1968). Escherichia coli KI2 strain 2578 represents a mutant (his, trp, str-r) of E. coli KI2 strain w3 100 originally from Drs E. and I. Lederberg's collection provided by Dr A. Rapin.

Escherichia coli $\mathrm{F} 504$ is an $\mathrm{R}$ mutant with the complete $E$. coli $\mathrm{RI}$ core structure derived from $E$. coli $\mathrm{O} 8: \mathrm{K}_{27}$. The $E$. coli $\mathrm{Hfr} 59\left(\mathrm{O} 8:{\mathrm{K} 27^{-}}^{-}\right)$has been previously described (Schmidt, I969). The origin and direction of chromosome transfer of the different donors used are indicated in Fig. 2.

Bacteriophages. The phages and their host strains are listed in Table 2. The phages Felix O (FO), Brio, FPI, C2I and 6SR have proved useful in characterization of Salmonella 


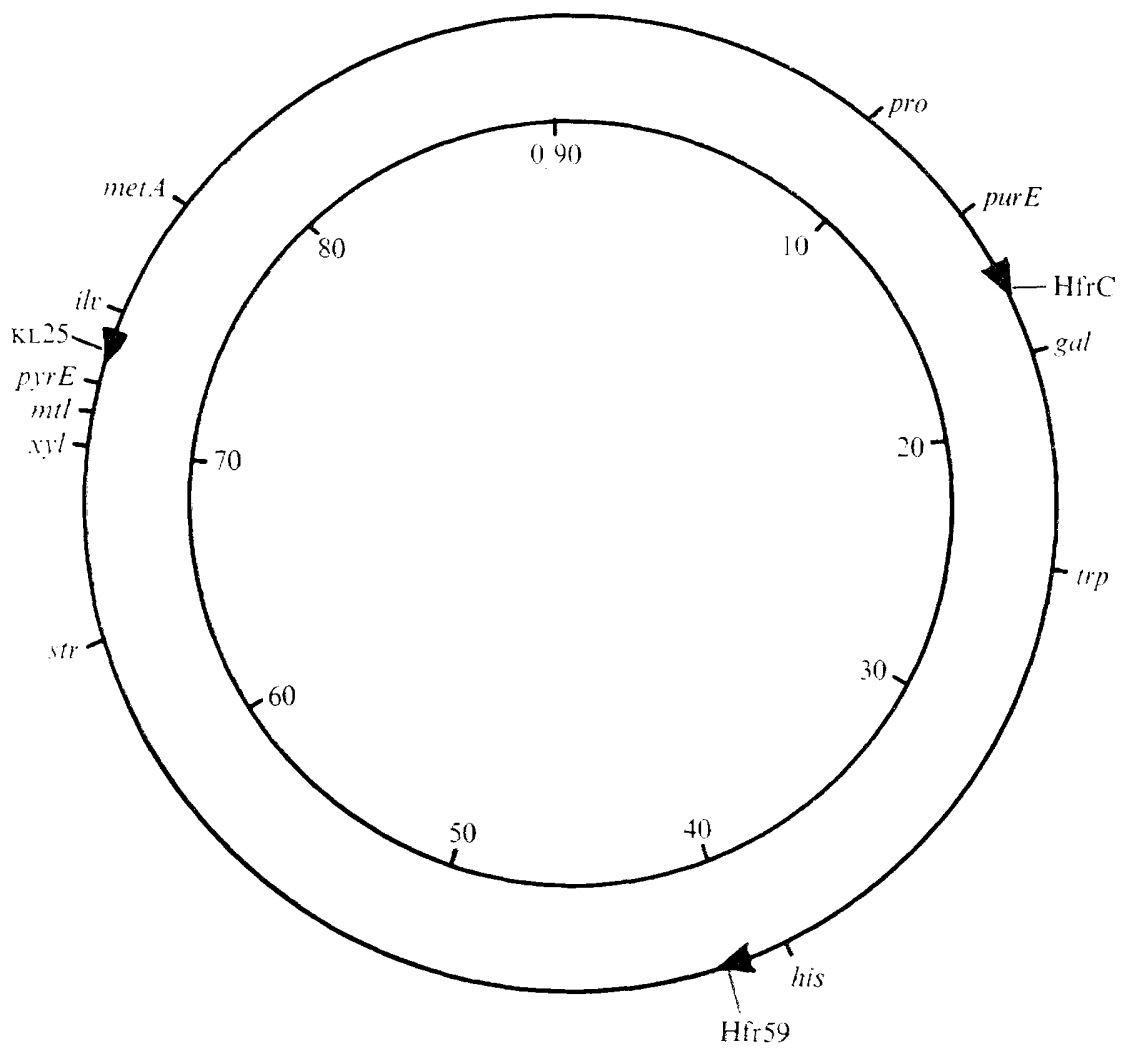

Fig. 2. Linkage map of Escherichia coli with some relevant markers. Origin and transfer direction of Hfr strains are indicated by arrows.

Table I. Escherichia coli strains used

\begin{tabular}{|c|c|c|c|}
\hline Strain no. & Serotype & Genetic markers & $\begin{array}{l}\text { Fertility } \\
\text { type }\end{array}$ \\
\hline w3100 & $\mathrm{K} 12$ & Prototroph & $\mathrm{F}^{-}$ \\
\hline 2578 & $\mathrm{~K} 12$ & his, trp, str-r & $\mathrm{F}^{-}$ \\
\hline KL25 & $\mathrm{K} 12$ & thi, str-s & $\mathrm{Hfr}$ \\
\hline $\mathrm{HfrC}$ & $\mathrm{K} 12$ & met, str-s & $\mathrm{Hfr}$ \\
\hline F504 & E. coli $\mathrm{R}$ I core & $m t l, x y l$, ara, met, his, str-r & $\mathrm{F}^{-}$ \\
\hline F459 & O8: $\mathrm{K} 27^{-}$ & $i l v, s t r-s$ & Hfr 59 \\
\hline
\end{tabular}

Symbols: his, trp, met, $i l, t h i$, for histidine, tly ptophane, methionine, isoleucine/valine, thiamine requirement; $m t l, x y l$ ara for non-fermentation of mannitol, xylose, arabinose; $s t r-s / r$ for streptomycin sensitivity resistance.

and $E$. coli $\mathrm{R}$ mutants (Schmidt \& Lüderitz, 1969; Schmidt, Jann \& Jann, 1970). Phage U3 was kindly provided by Dr K. Paigen, through Dr A. Rapin of this Institute. This phage lyses only wild-type KI2 strains, but not galE or galU mutants which have galactose or glucose-deficient LPS (Watson \& Paigen, 1971). Phage $\Omega 8$ is specific for Escherichia coli strains belonging to serotype O8 (Jann, Schmidt \& Wallenfels, I97I).

The phages were propagated on their respective host strains in meat extract broth (Adams, 1959). 
Table 2. Bacteriophages and their host strains

$\quad$ Phage
Felix-O (FO)
$\Omega 8$
BrIo
FPI
$\mathrm{C}_{21}$
6SR
$\mathrm{U}_{3}$
TI-T7

Host strain

Salmonella paratyphi в

Escherichia coli $\mathrm{O} 8: \mathrm{K}_{27}^{-}$

S. paratyphi B I/2

S. minnesota R5

S. typhimurium $\mathrm{SL} 869$

E. coli $\mathrm{F} 576$ (R2 core mutant)

E. coli $\mathrm{KI} 2$

E. coli $\mathrm{B}$

Phage sensitivity of strains was tested using suspensions containing about $10^{8}$ plaqueforming units $/ \mathrm{ml}$. Drops of phage suspension were placed on dried bacterial lawns on agar plates and incubated overnight at $37^{\circ} \mathrm{C}$.

Mating experiments. These were performed as previously described (Schmidt, Jann \& Jann, 1970). Recombinants were first transferred to the media used for selection and then streaked on complete agar medium from which single colonies were isolated.

Slide agglutination. The presence of the 08 antigen in recombinants was tested by slide agglutination tests in Escherichia coli $\mathrm{O} 8$ antiserum. In addition an E. coli $\mathrm{KI} 2$ antiserum containing antibodies specific to the K $\mathrm{I} 2$ core was used.

The antisera were diluted in $0.3 \%$ instead of $0.9 \% \mathrm{NaCl}$ solution to avoid a non-specific agglutination of rough forms.

Media. Solid complete medium was $\mathrm{D}_{1 \cdot 5}$-agar (Schlecht \& Westphal, 1967) with $0.3 \%$ glucose and $1.5 \%$ agar. Meat extract broth of the following composition was used (g/1 distilled water): Difco Bacto-Peptone, Io; $\mathrm{NaCl}, 3 ; \mathrm{Na}_{2} \mathrm{HPO}_{4} . \mathrm{I}_{2} \mathrm{H}_{2} \mathrm{O}, 2$; glucose, I ; Difco Beef-Extract, $5 ; \mathrm{pH} \mathrm{7.3.} \mathrm{For} \mathrm{selection} \mathrm{of} \mathrm{recombinants} \mathrm{from} \mathrm{mating} \mathrm{mixtures} \mathrm{Davis}$ minimal agar (Lederberg, I950) with $0.3 \%$ glucose was supplemented with the appropriate amino acids $(20 \mu \mathrm{g} / \mathrm{ml}$ agar). For selection of fermentation markers glucose was replaced by the appropriate sugar.

Serologic methods. Production of antisera and passive haemagglutination tests were performed as previously described (Schmidt, Fromme \& Mayer, 1970). Lipopolysaccharides used for haemagglutination were extracted by a mixture of phenol-chloroform-petrol ether as described by Galanos, Lüderitz \& Westphal (I969).

\section{RESULTS}

Characterization of Escherichia coli $\mathrm{KI} 2$ strains. The E. coli KI 2 strains listed in Table I showed rough colonial morphology and cells grown on $\mathrm{D}_{1 \cdot 5}$-agar were strongly agglutinated by $3.5 \% \mathrm{NaCl}$ or $0.3 \%$ auramine solution (Schmidt, Schlecht, Lüderitz \& Westphal, 1969) but only slightly by $0.9 \% \mathrm{NaCl}$. No agglutination was observed in $0.3 \%$ saline. Therefore the antisera used for testing recombinants in slide agglutination (see below) were diluted $\mathrm{I}: \mathrm{IO}$ in $0.3 \%$ saline.

In addition the sensitivity of the Escherichia coli KI2 strains to a number of roughspecific phages was tested. All four strains were sensitive to phages $\mathrm{U}_{3}, \mathrm{Brro}, \mathrm{FPr}$, and to the seven T-phages $\left(\mathrm{TI}-\mathrm{T}_{7}\right)$. Thus these KI 2 strains showed the typical traits of rough $(\mathrm{R})$ mutants.

No lysis was observed with the R-specific phages FO, $\mathrm{C}_{2} \mathrm{I}$ and 6SR. Of special interest is the sensitivity of the strains to phage $U_{3}$. This phage is known to attack 'wild-type' 
Table 3. Serological analysis and phage sensitivity of his ${ }^{+}$ recombinants from cross $\mathrm{H} f \mathrm{r} 5 \mathrm{9} \times 2578$

Slide agglutination* in

\begin{tabular}{|c|c|c|c|c|c|c|c|c|}
\hline \multirow{2}{*}{$\begin{array}{l}\text { No. of } \\
\text { recombinants }\end{array}$} & \multicolumn{2}{|c|}{ Antisera } & \multirow{2}{*}{$\begin{array}{l}\mathrm{NaCl} \\
3.5 \%\end{array}$} & \multicolumn{5}{|c|}{ Phage sensitivity†் } \\
\hline & O8 & KI2 & & $\Omega 8$ & Brro & FPI & $\mathrm{U}_{3}$ & $\mathbf{T}_{+}^{+}$ \\
\hline 78 & + & - & - & + & - & - & - & - \\
\hline 18 & + & + & - & + & + & + & + & + \\
\hline 4 & - & + & + & - & + & + & + & + \\
\hline \multicolumn{9}{|l|}{ Parent strains } \\
\hline Hfr59 & + & - & - & + & - & - & - & - \\
\hline 2578 & - & + & + & - & + & + & + & + \\
\hline
\end{tabular}

Escherichia coli KI2 strains but not mutants which have glucose or galactose deficient lipopolysaccharides (Watson \& Paigen, I97I). This suggests that the strains tested here have the unimpaired LPS of E. coli KI 2 . It should be noted that sensitivity of E. coli KI 2 towards phage 6 SR recently observed by Jones et al. (1972) reflects the use of phage 6SR-J propagated on E. coli KI 2 and later found to differ in respect of host range from other stocks of phage 6SR (Dr Stocker, personal communication). Phage 6SR-J was also active on the E. coli KI2 strains used here.

Introduction of the Escherichia coli $\mathrm{O} 8 \mathrm{rfb}$ region into E. coli $\mathrm{KI} 2$. The question arises whether $E$. coli $\mathrm{KI} 2$ synthesizes a complete or an incomplete LPS core structure. Incomplete core oligosaccharides lack the normal site for the O-specific polysaccharide attachment. To test whether the KI 2 core can attach $\mathrm{O}$-specific chains the intact $r f b$ locus of an $E$. coli $\mathrm{O} 8$ donor was introduced into $E$. coli $\mathrm{K} \mathrm{I} 2$. The $r f b$ locus is closely linked to his loci (Ørskov \& Orskov, 1962). Therefore $s t r-r, h i s^{+}$recombinants were selected from crosses of the $E$. coli donor Hfr59 (O8:K27-, his ${ }^{+}$, str-s) with E. coli KI 2 strain 2578 (his, trp, str-r) on suitably supplemented minimal agar containing streptomycin at $100 \mu \mathrm{g} / \mathrm{ml}$ agar to counter-select the streptomycin-sensitive donor. The his ${ }^{+}$recombinants were tested serologically by slide agglutination and also for phage sensitivity (see Table 3). Of I oo his ${ }^{+}$recombinants, 96 were agglutinated by $\mathrm{O} 8$ antiserum, a result which suggests that introduction of the intact donor $r f b$ region of $\mathrm{Hfr} 59$ enables the KI2 recipients to synthesize a LPS carrying O8-specific chains. Of the 96 O8-agglutinable recombinants, 78 were not agglutinated by $\mathrm{K} 12$ antiserum and were sensitive to phage $\Omega 8$, but not to phages $\mathrm{U}_{3}, \mathrm{Br}$ IO, FPI and to the $\mathrm{T}$ phages. They behaved like fully smooth $E$. coli strains; this indicates the presence of a complete core in $\mathrm{KI} 2$ recipient strain 2578 . The remaining I 8 O8-agglutinable $\mathrm{his}^{+}$recombinants were also agglutinated by KI 2 antiserum but not by auramine or $3.5 \%$ saline. They were sensitive to phage $\Omega 8$ and to rough-specific phages. These recombinants have a partly rough phenotype. In addition the sensitivity of two representatives of each recombinant group was tested by Dr Stocker, to other rough-specific phages (Br6o, Br2, Ffm not used here) and to a series of colicins active on E. coli KI2 (see Jones et al. 1972). As expected, the fully smooth recombinants were resistant and the partly rough strains were, like the parental E. coli KI2, also sensitive to these phages and colicins.

The partly rough recombinants were stable in their phenotypic expression, for no other classes segregated out following single colony isolations. In contrast, the fully smooth recombinants were unstable. Thus in some cases they segregated colonies which resemble 
Table 4. Phage sensitivity patterns of Escherichia coli $R$ mutants with

$\begin{array}{ccccccccc}\begin{array}{c}\text { Strain } \\ \text { no. }\end{array} & \begin{array}{c}\text { Derived } \\ \text { from } \text { E. coli }\end{array} & \begin{array}{l}\text { Core } \\ \text { type }\end{array} & \text { FO } & \text { Brio } & \text { FPI } & \text { C2I } & 6 \text { SR } & \text { U3 } \\ \text { F470 } & \text { O8:K27 } & \text { RI } & - & + & + & + & + & - \\ \text { F576* } & \text { O8:K42 } & \text { R2 } & + & + & + & - & + & - \\ \text { F653 } & 0111: \mathrm{K} 58 & \text { R3 } & - & + & + & - & + & - \\ 2578 & \text { K12 } & \text { KI2 } & - & + & + & - & - & +\end{array}$

* Salmonella Ra mutants show the sensitivity pattern of F576 using these phages. This correlates with the close structural relationship between these core types (see Hämmerling, Lüderitz, Westphal \& Mäkelä, 197r).

the partly rough recombinants in phage patterns and serological properties, and which retain the $\mathrm{His}^{+}$phenotype of the donor.

Studies comparing the Escherichia coli $\mathrm{KI} 2$ core with the known core types of E. coli and Salmonella. The formation of fully smooth his ${ }^{\dagger}$ recombinants in the crosses described above suggests the presence of a complete LPS core structure in E. coli K12 strain 2578. Three different complete LPS core types $(E$. coli $\mathrm{R} 1-\mathrm{R} 3)$ are known in $E$. coli serotypes which are distinct from the core present in Salmonella serotypes (Schmidt, Fromme \& Mayer, 1970). The relationship of the E. coli KI 2 core to already known core types was studied by passive haemagglutination tests. Comparing the serologic properties of the LPS isolated from representative core-type mutants and E. coli KI 2 it was found that the LPS of E. coli KI2 strain 2578 did not react in the heterologous antisera against E. coli RI, R2, R3 and Salmonella Ra-type mutants. Conversely the LPS of the E. coli and Salmonella core-type mutants showed no haemagglutination in anti-KI 2 serum. This suggests that the E. coli $\mathrm{Kr} 2$ core is serologically unrelated to the other already known core types of E. coli and Salmonella. This result is in full agreement with the finding that representative core type mutants and E. coli K12 exhibit distinct sensitivity patterns to a number of rough-specific phages (see Table 4).

Mapping the locus determining the Escherichia coli $\mathrm{K} 12$ core. To map the genes for the $\mathrm{KI} 2$ core oligosaccharide synthesis matings were performed between $E$. coli $\mathrm{K} I 2$ donors and the multiple marked $E$. coli $\mathrm{R}$ mutant F504 as recipient which has the complete coli RI core. After single colony-purification recombinants were tested for unselected markers. Their core type (E. coli RI or KI2) was inferred from their sensitivity pattern to appropriate phages. Thus recombinants which have inherited the genes for KI 2 core synthesis should be sensitive to the KI2-specific phage $\mathrm{U}_{3}$. The presence of the $E$. coli RI core in the recombinants could be detected by their sensitivity to phages C2I and 6SR and by their resistance to phage $\mathrm{U}_{3}$ (see Table 4 ).

Escherichia coli $\mathrm{F} 504$ was first mated with the E. coli $\mathrm{KI} 2$ donor KL25, which has a point of origin between pyrE and ilv and injects its chromosome clockwise (Fig. 2). Selections were made for $\mathrm{met}^{+}$, ara ${ }^{+}$, str-r and his ${ }^{+}$, str-r recombinants. Fifty recombinants of each class were isolated and tested by phage typing. None of these recombinants were able to synthesize a K 2 core; they all showed the typical phage pattern of E. coli $\mathrm{R}$ I mutants. Therefore the genes for the $\mathrm{K} 12$ core oligosaccharide do not lie between the origin and the his locus of the donor chromosome. In another cross $\mathrm{HfrC}$ was used as donor which injects its chromosome counterclockwise with purE as the leading locus (Fig. 2). In this case $m t l^{+}$ $s t r-r$ and $x y l^{+} s t r-r$ recombinants were selected. Among these recombinants a large number showed the typical phage pattern of $E$. coli $\mathrm{KI} 2$, indicating that they have inherited the genes for $\mathrm{K} 12$ core synthesis from the donor. 
Table 5. Passive haemagghtination of different $R$ lipopolysaccharides

$\quad$ R-LPS from
HfrC (KI2)
F504 (E. coli RI)
F870 (recombinant)

Reciprocal titre in antisera

$\begin{array}{cc}\text { E. coli } \mathrm{RI} & \mathrm{KI} 2 \\ <20 & \mathrm{I} 280 \\ 5 \mathrm{I} 20 & <20 \\ <20 & 640\end{array}$

Table 6. Inheritance of donor K 2 rfa locus among different recombinant classes of a cross between $\mathrm{Hfr} \mathrm{C}$ and Escherichia coli $\mathrm{F} 504$

Sensitivity to phage 6SR and $\mathrm{C}_{2} \mathrm{I}$ indicates the presence of the E. coli R I core; sensitivity to phage $\mathrm{U}_{3}$ was taken as evidence for the presence of the $E$. coli $\mathrm{K} 2 \mathrm{z}$ core resulting from a transfer of the donor $r f a$ locus.

\begin{tabular}{|c|c|c|c|c|}
\hline \multirow[b]{2}{*}{$\begin{array}{l}\text { Recombinant } \\
\text { class }\end{array}$} & \multirow[b]{2}{*}{$\begin{array}{l}\text { Total no. of } \\
\text { recombinants }\end{array}$} & \multicolumn{2}{|c|}{$\begin{array}{l}\text { No. of recombinants } \\
\text { with core type }\end{array}$} & \multirow{2}{*}{$\begin{array}{c}\text { Transfer fre- } \\
\text { quency of } \mathrm{K} 12 \\
r f a \text { locus } \\
(\%)\end{array}$} \\
\hline & & K 12 & coli $\mathrm{RI}$ & \\
\hline$x y l^{+} m l^{-}$ & 54 & 0 & 54 & 0 \\
\hline$x y l^{+} m t l^{+}$ & 176 & 100 & 76 & 57 \\
\hline$x y l^{-} m t l^{+}$ & 38 & 24 & 14 & 63 \\
\hline
\end{tabular}

The LPS of one of the KI2-like recombinants (F870, his, $x y l, m t l^{+}$, ara, met) was extracted and used in passive haemagglutination tests with $E$. coli $\mathrm{R} I$ and $\mathrm{KI} 2$ antisera. For comparison the results with LPS of the parent strains $\mathrm{HfrC}$ ( $\mathrm{KI}$ I2) and E. coli $\mathrm{F} 504$ (E. coli $\mathrm{RI}$ ) are included (see Table 5). The haemagglutination test shows that in addition to the phage sensitivity pattern the recombinant strain F870 synthesizes a LPS which is serologically identical with that of E. coli $\mathrm{Kr} 2$.

Results with three recombinant classes $m t l^{+} x y l^{-}, m t l^{-} x y l^{+}$and $m t l^{+} x y l^{+}$from the cross between $\mathrm{HfrC}$ and $\mathrm{F}_{504}$ are presented in detail in Table 6.

About $60 \%$ of the $m \mathrm{tl}^{+}$recombinants have received from the donor the genes for the KI 2 core synthesis. This clearly shows that this gene locus (termed $r f a$ according to usual nomenclature) is located close to $m t l$. Analysis of the different recombinant classes also gives information about the order of the three loci. $X y l^{+} \mathrm{mtl}^{-}$recombinants had not obtained the donor KI $2 r f a$ locus. Furthermore all those recombinants selected for $x y l^{+}$which have inherited the K $\mathrm{I} 2 \mathrm{ff}$ locus were also $m \mathrm{tl}^{+}$. Therefore the three loci are most probably in the order $x y l-m t l-r f a$. Moreover no quadruple crossover would be required among the 268 recombinants tested by this order, in contrast to other possible orders. Together with the negative results of the cross with Hfr KL25 this suggests that the K $12 \mathrm{rfa}$ locus lies between $m t l$ and the point of origin of the Hfr KL25 (see Fig. 2). The distance between $m t l$ and the if $a$ locus can be estimated as follows. On the linkage map of Escherichia coli (Taylor, 1970) there is a $\mathrm{I}$ min distance between the $m t l$ and the $x y l$ loci. In the crosses described here the linkage observed between these loci is about $65 \%$ and between $m t l$ and $r f a$ about $60 \%$ (see Table 6 , column 5). Therefore one can estimate that $r f a$ maps about I min distance from $m t l$ - that is, about $72 \mathrm{~min}$ on the E. coli linkage map.

\section{DISCUSSION}

Previous investigations indicated that phenotypically rough Escherichia coli $\mathrm{KI} 2$ has defective $r f b$ genes resulting in a lack of O-chain synthesis (Ørskov \& Orskov, 1962; Jones et al. 1972). 
The introduction of the his-linked $r f b$ region from the Escherichia coli O8 donor Hfr59 into $E$. coli KI2 strain 2578 led to smooth recombinants which have serological O8 specificity and resemble the parental $E$. coli $\mathrm{O} 8$. This suggests that $E$. coli $\mathrm{KI} 2$ has a complete LPS core structure which can attach O8-specific chains. Moreover, recent studies (Jann, unpublished) established that in recombinants the O8-specific polymer, which is a mannan (Reske \& Jann, I972), is covalently bound to the KI 2 core oligosaccharide chain.

Some O8-reactive $\mathrm{his}^{+}$recombinants from matings between the Escherichia coli O8 donor Hfr59 and the E. coli KI 2 strain 2578 were partly rough (see Table 3 ). Moreover, in some cases smooth $h i{ }^{+}$recombinants can segregate partly rough forms, which remain stable with respect to the histidine character. Therefore it is likely that some or possibly all of the smooth recombinants are partial diploids for donor gene(s) involved in LPS synthesis, and that they segregate haploids showing a partly rough phenotype as a result of the loss of this donor gene(s). The partly rough forms remained agglutinable by anti-KI 2 serum and retained sensitivity to various rough-specific phages characteristic of the parental E. coli K 2 strain. This suggests that part of the LPS core stubs is not substituted by 08 repeat units and therefore remains accessible to KI 2 core-specific antibodies. Similarly, one can suggest that O chains, which obviously mask the receptor sites for rough-specific phages in fully smooth strains, are not present in adequate numbers on the cell surface of partly rough forms to prevent rough-specific phages from attaching to their respective receptor sites. Therefore the partly rough forms might have a partial defect in the enzymatic transfer of $\mathrm{O} 8$ units to the core.

Jones et al. (1972) also found partly rough but not fully smooth his ${ }^{+}$recombinants in crosses between the Escherichia coli $\mathrm{O} 8$ donor $\mathrm{Hfr} 59$ and an E. coli $\mathrm{KI} 2$ strain. Therefore it may be that $E$. coli $\mathrm{KI} 2$ strain 2578 used in this laboratory maintains partial diploidy more readily than the KI 2 strain used by Jones et al. (1972).

Escherichia coli KI2 shows a phage pattern which is distinct from those of other coretype mutants (see Table 4 ). The phage resistance of a given strain may result from DNA restriction rather than from failure of the phage to adsorb. But phage $\mathrm{U}_{3}$, which is a $\mathrm{KI} 2$ core-specific phage, failed to adsorb to resistant strains (unpublished observation), thus indicating the absence of corresponding receptor sites in these strains. These data suggest that the differences in phage sensitivity between $E$. coli $\mathrm{KI} 2$ and the other core-type strains is due to differences in their LPS core structures. The outcome of passive haemagglutination tests confirmed this suggestion.

In an earlier study $r f a$ genes for different steps of the core synthesis of Escherichia coli O8:K27 were found in the upper left quadrant of the chromosome near to $m t l$ (Schmidt, Jann \& Jann, 1970). In addition Eriksson, Grennberg, Nordström \& Englund (1971) have mapped the mutation site for ampicillin resistance of two $E$. coli KI 2 mutants near to $\mathrm{mtl}$. The LPS composition of both these mutants differed from each other and from that of the original E. coli $\mathrm{KI} 2$ and the genes were designated $L p s A$ and $L p s B$, respectively. These mutations may affect different $r f a$ genes concerned with the KI 2 core synthesis. In the present investigation with E. coli KI 2 a $r f a$ locus determining the KI2-type core oligosaccharide was located in the region $x y l-m t l-r f a$, with $r f a$ about $\mathrm{I}$ min from $m t l$. Together with recent results mentioned above concerning E. coli $\mathrm{O} 8: \mathrm{K} 27$ and E. coli $\mathrm{KI} 2$ it is assumed that this locus represents a cluster of different genes governing the synthesis of the core oligosaccharides in $E$. coli and is most likely equivalent to the Salmonella $r f a$ gene cluster which has been mapped between $c y s E$ and pyrE (Kuo \& Stocker, 1972; Sanderson \& Saeed, 1972). 
The paper is dedicated to Professor O. Westphal on the occasion of his 6oth birthday. I am greatly indebted to Dr Bruce Stocker, Stanford, and Dr K. Sanderson, Calgary, for helpful suggestions, and colleagues mentioned in the text for supplying bacterial strains. The excellent technical assistance of Mrs A. Gutmann and Miss U. Fischer is gratefully acknowledged.

\section{REFERENCES}

Adams, M. H. (I959). Bacteriophages. New York: Interscience Publishers.

Eriksson-Grennberg, K. G., Nordström, K. \& Englund, P. (197I). Resistance of Escherichia coli to penicillins. Journal of Bacteriology 108, $1210-1223$.

Galanos, C., Lüderitz, O. \& Westrhal, O. (1969). A new method for the extraction of R lipopolysaccharides. European Journal of Biochemistry 9, 244-249.

Hämmerling, G., Lüderitz, O., Westphal, O. \& Mäkelä, P. H. (I97I). Structural investigations on the core lipopolysaccharide of Escherichia coli or oo. European Journal of Biochemistry 22, 331-344.

JANN, K., SCHMIDT, G. \& WALlENFELs, B. (197I). Isolation and characterization of Escherichia coli bacteriophage 8 specific for E. coli strains belonging to sero group O8. Journal of General Microbiology 67, $289-297$.

Jones, R. T., Koeltzow, E. E. \& Stocker, B. A. D. (1972). Genetic transfer of Salmonella typhimurium and Escherichia coli lipopolysaccharide antigens to Escherichia coli KI2. Journal of Bacteriology III, $758-770$.

Kuo, T. \& Stocker, B. A. D. (I972) Mapping of $r$ fa genes in Salmonella typhimurium by ES I 8 and P 22 transduction and by conjugation. Journal of Bacteriology 112, 48-57.

LEDERBERG, J. (1950). Isolation and characterization of biochemical mutants of bacteria. Methods in Medical Research 3, 5-22.

Low, B. (1968). Formation of merodiploids in matings with a class of rec- recipient strains of Escherichia coli K 12. Proceedings of the National Academy of Sciences of the United States of America 60, I60-167.

LÜDERITZ, O., JANN, K. \& WHEAT, R. (I968). Somatic and capsular antigens of gram-negative bacteria. In Comprehensive Biochemistry, vol. 26 A, pp. 105-227. Edited by M. Florkin and E. H. Stotz. Amsterdam: Elsevier Publishing Company.

Lüderitz, O., Westphal, O., Staub, A. M. \& Nikaido, H. (1971). Isolation and chemical and immunological characterization of bacterial lipopolysaccharides. In Microbial Toxins, vol. 4, pp. I45-224. Edited by G. Weinbaum, S. Kadis and S. J. Ajl. New York: Academic Press.

Nikaido, H., Nikaido, K. \& Rapin, A. M. C. (1965). Biosynthesis of thymidine diphosphate L-rhamnose in E. coli $\mathrm{KI}$. Biochimica et biophysica acta $\mathbf{I I}, 54^{8}-55 \mathrm{I}$.

$\emptyset_{\mathrm{RSKOV}}$ F. \& ØRskov, I. (1962). Behaviour of Escherichia coli antigens in sexual recombination. Acta pathologica et microbiologica scandinavia 55, 99-109.

RAPIN, A. M. C. \& MAYER, H. (1966). Complex polysaccharides in different strains of Escherichia coli KI 2 . Annals of New York Academy of Sciences 133, 425-437.

RESKE, K. \& JANN, K. (1972). The O8 antigen of Escherichia coli. Structure of the polysaccharide chain. European Journal of Biochemistry 31, 320-328.

Sanderson, K. E. \& SAEed, Y. A. (1972). P22-mediated transduction analysis of the roughA $(r f a)$ region of the chromosome of Salmonella typhimurium. Journal of Bacteriology 112, 58-63.

Schlecht, S. \& WestPhal, O. (1967). Wachstum und Lipopolysaccharid-Gehalt von Salmonellen bei Züchtung auf Agarnährböden. Zentralblatt fïr Bakteriologie und Parasitenkunde (Originale) 200, $24 I-259$.

SCHмIDT, G. ( I969). Konjugation bei E. coli $\mathrm{O} 8: \mathrm{K}_{27}: \mathrm{H}^{-}$. Zentralblatt für Bakteriologie und Parasitenkunde (Originale) 21r, 335-344.

Schmidt, G., Fromme, I. \& Mayer, H. (1970). Immunochemical studies on core lipopolysaccharides of Enterobacteriaceae of different genera. European Journal of Biochemistry 14, 357-366.

Schmidt, G., J $J_{\mathrm{ANN}}$, B. \& $J_{\mathrm{ANN}}$, K. (1970). Studies on R mutants with an incomplete core, derived from Escherichia coli O8: K27. European Journal of Biochemistry 16, 382-392.

SCHMIDT, G. \& LüderITZ, O. (I969). Untersuchungen zur Typisierung von Salmonella R-Formen. II. Mitteilung. Zentralblatt für Bakteriologie und Parasitenkunde (Originale) 210, 381-387.

Schmidt, G., Schlecht, S., Lüderitz, O. \& WestPhal, O. (1969). Untersuchungen zur Typisierung von Salmonella R-Formen. I. Mitteilung. Zentralblatt fïr Bakteriologie und Parasitenkunde (Originale) 209, 483-496. 
STOCKER, B. A. D. \& MÄKeLÄ, H. P. (197I). Genetic aspects of biosynthesis and structure of Salmonella lipopolysaccharide. In Microbial Toxins, vol. 4, pp. 369-433. Edited by G. Weinbaum, S. Kadis and S. J. Ajl. New York: Academic Press.

Sugimoto, K. \& OKAZAKI, R. (1967). A new rhamnosyl compound in lipopolysaccharide preparations of Escherichia coli. Journal of Biochemistry 62, 373-383.

TAYLOR, A. L. (1970). Current linkage map of Escherichia coli. Bacteriological Reviews 34, I55-175.

Watson, G. \& Paigen, K. (1971). Isolation and characterization of an Escherichia coli bacteriophage requiring cell wall galactose. Journal of Virology 8, 669-674. 